\title{
Innovating in the textile industry: An uncoordinated dance between firms and their territory?
}

\section{Emilio Camarena-Gil ${ }^{\text {iD }}$, Carlos Garrigues², Francisco Puig ${ }^{3}$}

\begin{abstract}
Considering the process of innovation development, this paper aimed to examine the effect of different dimensions of proximity and the level of coordination that exists in a textile cluster. This study employed a qualitative method, based on indepth interviews that were conducted with two leading firms in a textile cluster in Valencia, Spain, which is subject to intense competition from producers in Asia. Firms were selected according to the criteria of innovation development and opportunity. This is a pilot study that precedes a more ambitious one. The results suggested that firms' innovations are developed in an isolated, discontinuous, marginal, and uncoordinated way, and clustering has a marginal effect. Furthermore, despite high geographical and cognitive proximity, low social proximity is maintained by the low level of trust between the firms. These findings may be of significant practical value for practitioners and institutions. Firms can gain a better understanding of the importance of being located in a cluster, as this is a key factor for their survival under intense competition. However, geographical proximity is not sufficient, and firms need to cooperate with each other and share their ideas and experiences. In addition, institutions should interact more with companies, speak their language, meet their needs, and devise strong cluster initiatives. This study provides a more comprehensive understanding of how institutions and firms interact within a cluster in the process of innovation development and elaborate upon different dimensions of proximity among firms.
\end{abstract}

Keywords: cluster, innovation, proximity, Spain, territory, textile-clothing

1 Emilio Camarena-Gil, Department of Business Management, University of Valencia, Avda Tarongers s/n, 46022 Valencia, Spain, e-mail: emilio.camarena@uv.es (ORCID ID: 0000-0003-0942-6211).

2 Carlos Garrigues, GESTOR Research Group, University of Valencia, Avda Tarongers s/n, 46022 Valencia, Spain, e-mail: garrigues1975@gmail.com

3 Francisco Puig, Department of Business Management, University of Valencia, Avda Tarongers s/n, 46022 Valencia, Spain, e-mail: francisco.puig@uv.es (ORCID ID: 0000-0002-0502-7363). 


\section{INTRODUCTION}

The effect of clustering on the competitiveness of companies is hardly a new topic in the business literature. Paradigmatic examples, such as Silicon Valley (USA) for information technologies or Castellón (Spain) for tiles, speak for themselves. In these territories, the local productive system (firms and other actors) has been developed. Every type of activity is carried out in the value chain, and the final effect is positive (Puig \& Marques, 2010). These cases are often used as a reference when analyzing successful companies. They provide a model for regional development and are a source of inspiration for academics and professionals alike (Molina-Morales \& Martínez-Fernández, 2003). The activities of these territories, and the manner in which such activities are carried out, provides a good road map to study other sectors such as the textile industry.

To analyze these geographic realities, the aspects that can be studied are varied. In terms of the implemented business model (how firms do business and compete), two factors are considered fundamental: a) structural (size, ownership, activity, etc.) and b) strategic (implemented responses and strategies) (Lambert \& Davidson, 2013). In the latter case, strategies such as internationalization or innovation are frequently used as a basis for research (Claver-Cortés, Marco-Lajara, Seva-Larrosa, \& Ruiz-Fernández, 2019). This does not come as a surprise; in a globalized world, innovation has become key to survival for textile firms (Golf-Laville \& Ortega-Colomer, 2012).

But what is the strategic relationship between the territory in which the firm is located and the implementation of innovations? A cluster represents the geographical space in which firms interact with companies and institutions that belong to the same sector and which are interrelated by ties of competition and cooperation (Porter, 1998). Authors including Baptista and Swann (1998) have demonstrated that when both aspects (company and territory) interact effectively, the region becomes a platform and a stimulus for innovation, and an excellent place to compete (as Silicon Valley or Castellón).

In the innovation process, the geographical and institutional proximity between the actors involved in this process promotes an understanding among the companies of what is transmitted to them by institutions, and at the same time, the institutions that belong to the cluster understand what the companies demand (Sivadas \& Dwyer, 2000; Albors-Garrigós, HervásOliver, \& Hidalgo, 2009). In addition to the aforementioned proximities, firms and institutions in the cluster also need other proximity dimensions to break down barriers to innovation development. Such proximity dimensions include cognitive (to share the same knowledge base), social (being part of the same 
social environment), and organizational (to belong to the same organization) proximities (Boschma, 2005; Balland, Boschma, \& Frenken, 2015). Moreover, thanks to externalities and spillovers, geographic clustering can help smaller firms to overcome their size constraints (Porter, 1998). However, sometimes both innovation and territory interact or "dance" in an uncoordinated way and produce unexpected results (Heinonen \& Ortega-Colomer, 2015).

Thus, this paper aims to examine the effect of different dimensions of proximity and the level of coordination that exists in a textile cluster in the process of innovation development. To this end, this study focused on one of the most important Spanish textile clusters and carried out indepth interviews with the executives of two representative companies. The interviews addressed issues related to the implementation of innovations, the influence of the territory in that process, and the level of the different dimensions of proximity that exist within the cluster.

This article is presented in six parts. Section 2 presents the literature review, which elaborates on the introduction, and explains the importance of innovation for growth, its conceptualization, and features, as well as the effect of proximity on innovation. Section 3 describes the research methodology and provides a brief description of the textile sector and the Valencian textile cluster. Section 4 presents the main results of the in-depth interviews and is followed by the discussion in section 5 . Section 6 presents conclusions that summarize the main findings. A series of proposals are outlined for coordinating this dance between firms and institutions, the limitations of the study are identified, and directions for further research are suggested.

\section{LITERATURE REVIEW}

\section{Concept of innovation}

Innovation is not a new phenomenon. Primitive societies sought natural resources to ensure their survival and exerted the minimum amount of effort in the performance of their tasks. Many classic authors regarded innovation as a factor that indirectly stimulates economic growth through its effects on the variables that influence it in a more direct way, such as the division of labor. However, academics such as Schumpeter (1982) and Solow (1956), among others, asserted that, in addition to capital and labor, innovation is a key factor for development and economic growth. Following this line of thought, other authors, such as Freeman (1987) and Porter (1998), posited that the acquisition of new and more advanced technologies is an important factor for a country or a region, such that innovation represents the only way, in the 
long term, that a country can more effectively develop a competitive position and promote sustainable economic growth. The concept of innovation is an open one, and it is subject to different interpretations (Tidd \& Bessant, $2018^{4}$ ), although all authors agree that innovation is a new concept that involves improving a product, service, or process, and results in significant effects on the particular environment.

The Organization for Economic Cooperation and Development (OECD) developed the Oslo Manual (OECD, 2005), which distinguishes between four different types of innovation and provides some reasons for their implementation. These four types of innovation include the following:

1) Product innovation: this type of innovation involves significant changes in the capabilities of goods and services, such that either, new products and services are developed, or substantial improvements are made to existing products and services.

2) Process innovation: represents significant changes in production and delivery methods.

3) Organizational innovation: refers to the implementation of new organizational methods. These can include changes in business practices, in the organization of the workplace, or in the firm's external relations.

4) Marketing innovation: involves the implementation of new marketing methods, for instance, product design, packaging, or pricing.

Innovation is an activity that is linked to company performance: "The ultimate reason (as to why companies innovate) is to improve firm performance, for example, by increasing demand or reducing costs" (OECD, 2005 , p. 29), and also by deeming innovation to include the implementation of a novelty and its introduction to the market, as opposed to its mere development. The factors that foster innovation are varied and their influence differs (see Table 1). For example, the organization of the workplace (or the territory) can enhance the exchange of knowledge with other organizations due to the proximity among the different actors.

Furthermore, the literature concurs that there are various mechanisms that might obstruct the implementation of innovation (Table 2). For example, such mechanisms include the weaknesses of institutions (associations, institutes, etc.) in terms of their equipment or, in other words, their uncoordinated policies for innovation (Bramwell, Nelles, \& Wolfe, 2008).

4 The authors mention no less than six different definitions of innovation (Tidd \& Bessant, 2018), quoting scholars such as Peter Drucker and Michael Porter or entrepreneurs such as Richard Branson. 
Table 1. Factors that foster innovation

\begin{tabular}{|c|c|c|c|}
\hline $\begin{array}{l}\text { Competitors, } \\
\text { demand, and } \\
\text { markets }\end{array}$ & $\begin{array}{l}\text { Production and } \\
\text { distribution }\end{array}$ & $\begin{array}{l}\text { Organization of } \\
\text { the workplace }\end{array}$ & Other factors \\
\hline $\begin{array}{l}\text { Increase market } \\
\text { share }\end{array}$ & $\begin{array}{l}\text { Enhance the } \\
\text { quality level }\end{array}$ & $\begin{array}{l}\text { Enhance internal } \\
\text { communication in } \\
\text { the firm }\end{array}$ & $\begin{array}{l}\text { Reduce the } \\
\text { environmental } \\
\text { footprint }\end{array}$ \\
\hline $\begin{array}{l}\text { Widen the product } \\
\text { portfolio }\end{array}$ & $\begin{array}{l}\text { Diminish costs } \\
\text { and reduce } \\
\text { raw materials } \\
\text { and energy } \\
\text { consumption }\end{array}$ & $\begin{array}{l}\text { Exchange } \\
\text { knowledge with } \\
\text { other organizations }\end{array}$ & $\begin{array}{l}\text { Increase safety and } \\
\text { health }\end{array}$ \\
\hline $\begin{array}{l}\text { Adapt more quickly } \\
\text { to customers' } \\
\text { needs }\end{array}$ & $\begin{array}{l}\text { Increase efficiency } \\
\text { and capacity }\end{array}$ & $\begin{array}{l}\text { Enhance work } \\
\text { conditions }\end{array}$ & Follow the rules \\
\hline
\end{tabular}

Table 2. Factors hindering innovation

\begin{tabular}{|c|c|c|c|}
\hline Economic factors & $\begin{array}{l}\text { Factors related to } \\
\text { knowledge }\end{array}$ & $\begin{array}{l}\text { Factors related to } \\
\text { markets }\end{array}$ & $\begin{array}{l}\text { Institutional } \\
\text { factors }\end{array}$ \\
\hline $\begin{array}{l}\text { High innovation } \\
\text { costs }\end{array}$ & $\begin{array}{l}\text { Lack of necessary } \\
\text { knowledge }\end{array}$ & $\begin{array}{l}\text { Uncertainty. } \\
\text { Demand can be } \\
\text { low, and hence, } \\
\text { innovation } \\
\text { costs cannot be } \\
\text { recovered. }\end{array}$ & $\begin{array}{l}\text { Lack of necessary } \\
\text { infrastructure and } \\
\text { technology. }\end{array}$ \\
\hline $\begin{array}{l}\text { Risks and } \\
\text { uncertainty }\end{array}$ & $\begin{array}{l}\text { Lack of qualified } \\
\text { personnel }\end{array}$ & $\begin{array}{l}\text { Potential market } \\
\text { already dominated } \\
\text { by incumbents }\end{array}$ & $\begin{array}{l}\text { Legislation } \\
\text { does not favor } \\
\text { a determinate } \\
\text { innovation: } \\
\text { environmental, } \\
\text { fiscal,... }\end{array}$ \\
\hline
\end{tabular}

Source: own elaboration based on OECD (2005).

\section{Territory, proximity, and innovation}

The concept of proximity, which relates to innovation and the dissemination of knowledge, has followed a process that can be compared to the distance dimensions that are observed between countries, as described in International Business (IB) literature. In 2001, Pankaj Ghemawat (Ghemawat, 2001) introduced the CAGE framework, which identifies several distance dimensions: 
- cultural: refers to differences in religious beliefs, race, and social norms that determine how people interact with one another and with companies and institutions;

- administrative: expressed as the existence of historical or political connections, political hostility, or institutional weaknesses;

- geographical: calculated as the physical (i.e., transport) distance between two countries;

- economic: reflects differences in income between nationals of different countries or differences in the costs of resources.

In the exchange of knowledge, and in particular, in the development of innovation, the reverse concept is used. The cluster literature has always advocated the importance of the physical distance between companies (or, more precisely, the lack thereof) in relation to the definition and delimitation of a cluster, as well as its influence on the performance of the firms located within it. It was not until the early works of the French School of Proximity (Torre \& Rallet, 2005), and especially those of Boschma and his collaborators (Boschma, 2005; Balland et al., 2015), that different dimensions of proximity were added to the equation in an effort to explain their impact on successful knowledge interchange and potential innovations.

According to Boschma (2005), proximity can be measured according to five different dimensions (i.e., cognitive, social, geographical, organizational, and institutional). Importantly, he pointed out that negative effects arise from too little proximity between actors (this is, actors are distant from each other), and/or actors that are too close to each other. Thus, proximity is a variable that should be optimized, rather than minimized. Delving deeper into this concept, Molina-Morales, Belso-Martínez, Más-Verdú, and MartínezCháfer (2015) posited that attention should be given to the formation and dissolution of inter-firm linkages, as the development of innovation is based on such linkages. By studying a mature cluster of footwear firms in Spain, they found a relationship between the different dimensions of proximity and the creation of inter-firm linkages. We can refer to these conclusions in the present study, as the cluster presented in this paper is also mature ${ }^{5}$. Having reviewed Boschma's observations regarding the different dimensions of proximity and their relationship with innovation, we identified:

\section{Cognitive proximity}

Cognitive proximity is the shared knowledge base that enables communication between the actors (Boschma, 2005). It is also helpful for understanding

5 The textile activity in the region started well before the 20th century. It first took advantage of the available hydraulic power, then of steam power engines. ATEVAL, the association of firms in the sector, was founded in 1977, and AITEX, the technological institute, started its activities in 1985. 
and processing new information. Too much proximity may lead to a lack of sources of novelty, increase the risk of lock-in and undesirable knowledge spillovers, and will inevitably result in problems of communication, as the actors are unable to exchange actionable information (Nooteboom, 2000). Contrastingly, low cognitive proximity, in terms of competences and skills, enables communication (Boschma, 2005).

In a mature cluster in Spain, Molina-Morales et al. (2015) found that too much cognitive proximity negatively affected the creation of linkages, which are a key element for the exchange of information and interactive learning. In contrast, Lazzeretti and Cappone (2016) studied the ties between entities in the high technology consumer goods cluster in Tuscany, Italy ${ }^{6}$. They revealed that cognitive proximity promoted the formation of ties, not only in the initial phase of the cluster but also, albeit to a lesser extent, in the later cluster stages.

The location of the firm in a cluster may help to attain the optimum level of cognitive proximity (Maskell, 2001), as clusters consist of firms that share a common knowledge base, and the knowledge creation that is generated among them occurs through variation as well as by means of a deepening division of labor. Their knowledge base consists of diverse, albeit complementary, resources. Co-location within the same cluster allows the local actors to closely monitor each other and share their cognitive base while preserving the diversity that is necessary for interactive learning (Boschma, 2005). As a consequence of the division of labor and specialization, the knowledge bases of the different firms diverge, which stimulates deeper learning. Because of growing specializations, the knowledge bases of firms diverge to such an extent that interactive learning is stimulated, although communication is hindered by too much divergence.

\section{Social proximity}

Social proximity is derived from embeddedness theory (Granovetter, 1985), which posits that economic relations occur while being embedded in a social context, such that social relations also affect the economic results of these relations. Social proximity is defined at a micro-level ${ }^{7}$, and these relations are thought to be embedded when they are based on trust, which arises from friendship and regular intercourse. This form of trust eases

\footnotetext{
6 This cluster is composed of firms that work in the fields of geology, IT, chemistry, biology, and engineering, which mainly concentrate on the restoration of areas that have a rich cultural heritage. In addition to these big and small firms, one has to add several universities (e.g., Pisa, Florence and Padova), research institutions, and other knowledge providers. In contrast with the foodstuff and textile clusters in Valencia which were mentioned in the article, it can be considered a young cluster. 7 This social proximity, as defined at a micro level, is not to be confused with the adherence to a set of values as religious or ethnic values. This more macro level of proximity will be dealt with when explaining the institutional proximity concept.
} 
the transfer of tacit knowledge, which is rarely exchanged through market mechanisms (Maskell \& Malmberg, 1999).

This notion is formed from the rationale that a low level of social proximity affects the building of trust, resulting in a low level of knowledge interchange, which thereby impedes the development of innovations. However, the opposite situation also presents an unwelcome effect. Too much social proximity may cause the actors to underestimate the possibility of opportunism and, when maintained over a long period, this causes the actors to be locked into the established way of doing things, instead of using their capacity to learn and innovate (Uzzi, 1997).

Locating in an industrial cluster territory may compensate for the negative consequences that arise from too much social proximity: Networks that have overly tight bonds will "dissolve" because, in an agglomeration, agents have greater opportunities to establish relations with other parties and to accede to networks of a supra-regional level (Gordon \& McCann, 2000). Location can also enhance social proximity via geographical proximity, and firms can benefit from frequent contacts as well as greater opportunities to build trust.

\section{Organizational proximity}

While Boschma (2005) argued that it is necessary to share a common knowledge base and common competencies in order to approach firms and generate knowledge, it is also true that knowledge creation depends on the coordination of the exchange of complementary knowledge both inside and outside organizations. Organizational issues are coordination mechanisms, and they are also the vehicles of these exchanges.

Organizational proximity enhances learning and encourages innovation development, and it is associated with several degrees of intensity, from a pure spot relation between the actors, which is an example of low organizational proximity, to a hierarchically organized firm or network that has strong linkages. Close organizational proximity promotes innovation development as it ensures the rights of ownership over such development. However, too much organizational proximity leads to a lack of flexibility in respect to the implementation of innovations, and organizational lock-in can prevent access to novelty, resulting in insufficient feedback mechanisms that are critical for knowledge development (Blanc \& Sierra, 1999). It is believed that an organizational arrangement, which is composed of divisions that have a sizeable degree of autonomy, or of trust-based networks between the organizations (Nooteboom, 2000), may guarantee the desired level of flexibility, while also ensuring close organizational proximity. 


\section{Institutional proximity}

Institutional proximity is associated with the institutional framework at a macro level. In contrast to social proximity, institutional proximity is formed by the relationships among actors at a macro-level. North (1990) differentiated between a macro-level institutional environment (e.g., norms and values related to conduct) and a micro-level institutional environment in which norms and values are embedded in specific interchange relations.

Edquist and Johnson defined institutions as "sets of common habits, routines, established practices, roles, or laws that regulate the relations and interactions between individuals and groups" (Edquist \& Johnson, 1997, p. 46). Formal institutions (laws and norms) and informal institutions (cultural norms and habits) influence how the actors coordinate their tasks. These institutions influence how knowledge is interchanged and how innovation is developed (Boschma, 2005), by minimizing opportunism and uncertainty.

In this sense, institutional proximity is a factor that enables knowledge interchange and innovation development (Heinonen \& Ortega-Colomer, 2015). However, as observed in the case of the other proximity dimensions, institutional proximity can be detrimental to innovation development, particularly when its level is excessive. When there is too much institutional proximity, episodes of institutional lock-in can occur, blinding the actors to new possibilities, which intensifies institutional inertia and impedes essential institutional re-adjustments (Bramwell et al., 2008). This situation can be avoided by implementing a system of institutional checks and balances (Herrigel, 1993), which can promote institutional stability while also encouraging openness and flexibility. This system facilitates the necessary political checks and balances that allow for political change, and encourages changes in laws and norms. It can furthermore prevent power from accumulating in the hands of the actors, which could lead to control of the system. Molina-Morales et al. (2015) confirmed this effect when they verified that too much institutional proximity hinders the creation of linkages in a mature cluster. In contrast, Lazzeretti and Capone (2016) found that institutional proximity enhances the formation of ties in the early stages of a cluster as well as in later stages, although the latter case was observed with less intensity.

\section{Geographical proximity}

Geographical proximity is defined as the spatial (or physical) distance between economic actors, in both a relative and absolute sense (Boschma, 2005). A smaller distance between actors enhances information exchange, 
thus facilitating the transfer of tacit knowledge. In respect to knowledge sources, a short distance increases the level of innovative performance (Audretsch \& Feldman, 1996).

However, geographical proximity per se is neither a necessary nor sufficient condition for interactive learning to occur. Other forms of proximity can serve as substitutes for geographical proximity (Grabher, lbert, \& Flohr, 2008). Learning networks do not need a spatial limitation, and tacit knowledge can be transmitted across large distances provided that a standard of organizational proximity exists (through the coordination of tasks carried out by a central body) and that there is a given level of cognitive proximity between actors so that the knowledge can be absorbed (Rallet \& Torre, 1999). Similarly, if geographical proximity is not complemented by a minimum level of cognitive proximity, it is insufficient for the effective transmission of knowledge.

Geographical proximity can be achieved by firms that belong to the same cluster, as the distances involved are small in scale. However, too much proximity can lead the firms in a region to be too inward-looking. This resulting lack of openness to the outside world can affect the cognitive proximity of actors, which is aggravated in the case of specialized regions, and this situation has been observed to occur in a cluster (Boschma, 2005). This spatial lock-in can be avoided by forming linkages with partners outside the region while also maintaining close links with local actors. Molina-Morales et al. (2015) found close geographical and social proximities in the case of firms located in a mature cluster, and such proximities had a positive effect on the formation of inter-firm linkages, which is a prerequisite for achieving information exchange. This effect was also observed by Lazzeretti and Capone (2016) in both the early and later stages of the cluster's life, although in the last stages of the cluster, the intensity of the effect was lower. By researching cluster initiatives, Lis (2019) observed that geographical proximity had the same effect on cooperative relationships between firms.

The different dimensions of proximity can influence the information exchanges between actors in the cluster. By researching the level of the different dimensions of proximity within the cluster, we can obtain valuable information about how innovations developed within it, as innovation is based on knowledge exchanges between actors.

\section{Innovation and clustering effect}

Industrial districts and clusters are two models of production organization which propose, simultaneously, two approaches of economic development that consider territorial location to be fundamental, and both suggest developing models of production and exchange based on the binomial 
company and society. According to the literature, an industrial district can be understood as a "socio-territorial entity characterized by the active presence of a community of people and a population of companies in a natural and historically determined area" (Becattini, 2015). We define clustering as the action through which firms concentrate, and their interaction is considered in both a geographical and sectorial sense (Schmitz, 1992). This action results in the formation of clusters (Albors-Garrigós et al., 2009) that have a significant effect on the companies that are located within them, particularly in terms of the introduction of manufacturing innovations (Baptista \& Swann, 1998), financial performance differences (for instance, profitability), as well as non-financial differences (i.e., internationalization), which are measured in relation to their location inside or outside the agglomeration (Molina-Morales, 2001; Rodríguez-Victoria, Puig, \& Gonzalez-Loureiro, 2017). Therefore, the "territory effect" is a structural feature within the manufacturing sector, and it results in a relevant territorial specialization and encourages a higher entrepreneurial activity rate in the area (Delgado, Porter, \& Stern, 2010). This entrepreneurial attitude means that both new and existing companies are concerned about the implementation of renewal and innovation policies.

The main advantage of a cluster lies in how it contributes to improving the competitive advantage of the companies that are located within it, which thus increases the competitiveness of the cluster as well as that of the region where the cluster is located (Martin \& Sunley, 2003). Porter (1998) suggested that this is due to the relationships that exist between the companies, which positively influence the four vertices that determine the diamond or rhombus that explains the competitive advantage. Following the guidelines of Porter (1998), we can further specify the factors that encourage these competitive improvements to take place by classifying them into three basic categories as follows:

1) Productivity enhancements: this occurs as a result of specialization, the complementarity of the activities of the actors (participating companies), the increase in the bargaining power of companies, and the reduction in transaction costs.

2) Promotion of innovation: as a result of a greater ability to perceive new customer needs, new technological, commercial, or productive possibilities through joint research are made possible.

3) Creation of new companies: thanks to the reduced level of risk and lower entry barriers, as well as established relationships and potential customers for new companies.

Empirical evidence identified a "clustering effect» on productivity, innovation rates, and entrepreneurial attitudes (Molina-Morales \& MartínezFernández, 2003; Puig, González-Loureiro, \& Marques, 2014, RodríguezVictoria et al., 2017; Claver-Cortés et al., 2019). These externalities can be 
explained by three types of advantages that are difficult to achieve using another approach (Camisón, 2004):

1) Shared advantages: within a cluster, the development of ideas about competition and cooperation.

2) Competitive advantages: based on identifying competencies, and on differentiating elements of the companies that belong to a cluster which allow them to compete more effectively.

3) Comparative advantages: these types of advantages include the territory in which the companies are located. For example, it is worth mentioning that the Ontinyent area is the "capital" of the textile cluster at a regional level, and is home to almost $44 \%$ of the companies. Within the cluster area, around $33 \%$ of the manufacturing companies are associated with the traditional textile company.

Therefore, this organizational model, which is based on geographical proximity, is an important stimulus for innovation and the sustainability of companies, as it favors competitiveness: Some textile companies would not have grown to such a significant extent had they been located in another part of Spain (Puig \& Marques, 2010). Clusters extend vertically in the value chain which includes suppliers and auxiliary industries, and they also extend horizontally or transversally, by incorporating knowledge providers, public institutions, educational institutions, industrial parks, technological institutes, information services, recycling, and technical support firms, which are key to implementing innovations (Golf-Laville \& Ortega-Colomer, 2012). However, while geographical proximity is a necessary prerequisite for the organizational model, it is by no means sufficient for the effective coordination of the incumbent firms.

\section{RESEARCH METHODS}

\section{Research design, approach, and cases}

Our study is based on qualitative research. Qualitative data represent nonnumeric data which have been obtained by employing different research strategies (Saunders, Lewis, \& Thornhill, 2009). Qualitative research aims to obtain rich information about people's lives, experiences, behaviors, social movements, cultural phenomena, or management (Yin, 2018), which cannot be represented by numbers. In its broadest sense, the term "qualitative methodology" refers to research that produces descriptive data: The written or spoken words or the observable behavior of the individuals being studied (Taylor, Bogdan, \& DeVault, 2015). Qualitative methods can be used to obtain complex details about some phenomena, such as feelings, thought processes 
and emotions, which are difficult to extract using other more conventional research methods (Yin, 2018; Najda-Janoszka \& Daba-Buzoianu, 2018).

The sample consists of two companies dedicated to the textile industry, which are located in Ontinyent territory. In line with Tognazzo and Mazzurana (2017), we explored only two cases for several reasons: a) this study is the first step towards a more ambitious research project; b) by selecting two cases, we were able to carry out a more comprehensive analysis, allowing us to acquire and report our experiences with the gathering of new and unfamiliar data (von Krogh, Spaeth, \& Lakhani, 2003); c) as Dyer and Wilkins stated: "Moreover, because Eisenhardt argues that the more cases a researcher studies, the better (within certain limits) for generating theory, she seems to lose the essence of case study research: The careful study of a single case allows researchers to identify new theoretical relationships and question old ones" (Dyer \& Wilkins, 1991, p. 614).

According to Puig and Marques (2010), the productive process of the textile industry can be summarized as a cycle that involves spinning, weaving and dyeing, finishing, and dressmaking, which transforms a series of inputs (fibers, chemical products, etc.) into outputs or final products. These products can be highly varied (Canals, 2003), and may include blankets, bedspreads, carpets, sports clothing, and clothing from technical textiles, etc. In this process, it is important to point out that each link contributes to the elaboration of a finished product with added value, such that there is an interaction between the different links. The alteration or disappearance of any of these links would only endanger the continuity of the other companies located along the chain. In this sense, globalization has triggered some unbalances in the value chain, leading to the closure of some companies, or to an increase in the price of some raw materials and semi-finished products. Hence, the importance of innovation processes and continuous training for human resources to further enhance their skills, as well as the Industry 4.0 processes, all of which aim to support the entirety of the production process.

Historically, Spain's textile industry, which is a mature sector, has played an important role in the country's industrial development. According to data from 2013, 1.7 million people were employed by 185,000 European companies in the industry, which generated a turnover of 166 billion EUR. The sector accounts for a $3 \%$ share of value-added and a $6 \%$ share of employment in total manufacturing in Europe. The sector in the EU is based around small businesses (European Commission, 2019).

The textile industry in Spain is traditionally associated with two regions, namely, Catalonia and the Valencian Community. The Valencian textile cluster is formed by firms located in the counties of La Vall d'Albaida, el Comtat, and L'Alcoià, and it is composed of around 500 firms, with a total staff of 4,100 
employees. In this cluster, the main agglomeration of firms is located in the city of Ontinyent, which accounts for almost $33 \%$ of the activity (ATEVAL, 2017). In the Ontinyent region, the textile companies that prevail are small and medium-sized firms, many of which are family businesses, in the same vein as those in other South European countries such as Portugal or Italy (European Commission, 2019).

To ensure confidentiality, the firms which were studied are referred to as Alpha company and Beta company. The selection of these companies was based on criteria including relevance (i.e., the implementation of innovation initiatives, as confirmed by the information retrieved from our contacts in the cluster) and opportunity (i.e., their willingness to participate in the study).

This analysis, upon which our study is based, has allowed us to understand how innovation has developed within the cluster, the role of the different dimensions of proximity in its development, and the degree of coordination between the institutions and firms in the cluster. The features of the participating companies are shown in Table 3. Both are bigger than the average firm in the cluster ( 9 employees) and the age of around 25 years. The interviews with these companies were carried out in February of 2017, and the interviewees included either CEOs or members of the Executive Committees of the firms.

The collection of information derives from a series of in-depth interviews, which were conducted with these two companies, as well as a participatory observation of the daily work performed by their top executive managers. These interviews took place during the first months of 2017. The recordings were transcribed and then coded manually, searching for information about the diverse aspects related to the object of this research (i.e., how innovation was developed, the effect of clustering in this development, level of proximities in the cluster and their effects, degree of coordination between the actors of the territory). The interviews were structured in three parts: 1) introductory questions from which we obtained basic information about the companies, its vision, and the future of their industry; 2) innovation implemented, with the objective of understanding the level and types of innovations achieved by the firms, and 3) influence of clustering and the role of institutions and proximity in these processes. 
Table 3. Features of the firms in the sample

\begin{tabular}{|c|c|c|}
\hline Variables & Alpha company & Beta company \\
\hline Turnover (2016) & Around 12 million EUR & Around 3 million EUR \\
\hline $\begin{array}{l}\text { Turnover (2016) per } \\
\text { employee }\end{array}$ & 120,000 EUR & 100,000 EUR \\
\hline $\begin{array}{l}\text { Operating result } \\
(2016)\end{array}$ & $\begin{array}{l}\text { Around (- 500,000 EUR) } \\
\text { (loss) }\end{array}$ & Around $+300,000$ EUR (profit) \\
\hline $\begin{array}{l}\text { Employees (as of } \\
\text { the end of 2016) }\end{array}$ & Around 100 & Around 30 \\
\hline Type of products & $\begin{array}{l}\text { Household textiles } \\
\text { (blankets, pillows...) }\end{array}$ & $\begin{array}{l}\text { Sewing of sporting apparel } \\
\text { based on technical textiles }\end{array}$ \\
\hline Ownership & Worker's Cooperative & Family firm \\
\hline NACE Rev 2 Code & $\begin{array}{l}\text { 1392: Manufacture of } \\
\text { made-up textile articles, } \\
\text { except apparel }\end{array}$ & $\begin{array}{l}1431 \text { Manufacture of knitted } \\
\text { and crocheted hosiery }\end{array}$ \\
\hline Company type & Worker's Cooperative & $\begin{array}{l}\text { Private limited liability } \\
\text { company }\end{array}$ \\
\hline Type of innovation & $\begin{array}{l}\text { Product, process, } \\
\text { marketing innovation }\end{array}$ & $\begin{array}{l}\text { Product, process, } \\
\text { marketing innovation }\end{array}$ \\
\hline Interviewee & $\begin{array}{l}\text { Member of the Executive } \\
\text { Committee }\end{array}$ & General Manager \\
\hline
\end{tabular}

\section{ANALYSIS AND RESEARCH RESULTS}

\section{Vision and future of the textile-clothing industry}

As described in the theoretical framework, the new global economy and the progressive economic and social transformations that have taken place in recent years are bringing about a competitive rearrangement of each one of the phases along the value chain of the sector, from what is to be manufactured to what is to be sold.

Both of the managers who were interviewed agreed that they operate in a mature and traditional sector that experiences significant competition from emerging economies. These aspects are in line with other studies, such as those carried out by Costa and Duch (2005) or Cerverón and Ybarra (2016). Nevertheless, the dynamism that this industry possesses, in terms of renewal, innovation, and internationalization, encouraged a positive vision of the future among the managers of both of the companies. The main results of the interviews were triangulated and contrasted with relevant members of the territory. 
In conclusion, both companies had to innovate processes to subsequently manufacture the desired products; the Alpha company produced new blankets, and the Beta company diversified its products and finishes. It is also important to mention that both companies utilize Industry 4.0 technology in their production process, which is an essential resource in maintaining competitiveness, and it furthermore contributes to their medium and longterm sustainability (Müller, Kiel, \& Voigt, 2018).

It is worth noting that the CEO of one of the firms studied hinted that "...one of the features of this sector is its high level of competence. Until some years ago, it was unthinkable to expect firms in the sector to gather at a conference or an event". Shortly afterward, the same person stated that "unless ATEVAL" acts as a catalyzer among the textile firms, trust between them could not be built, and then the opportunities for cooperation will not show." We believe that this is the role of the institutions in the cluster; they are bodies that enhance organizational proximity, which is based on the establishment of trust-based networks between organizations that facilitate close organizational proximity while also maintaining flexibility, as mentioned previously (Nooteboom, 2000). These reflections are in line with the study of Sydow and Staber (2002).

\section{Implementation of innovation}

At this point, the following question arises: How did the firms in this study carry out the innovations? We asked whether innovations were carried out internally (i.e., using their own resources), or by means of external resources (i.e., via synergies with other companies in the sector, as well as by engaging with institutions such as AITEX, ATEVAL, etc.). ${ }^{9}$

\section{Alpha company}

"Our innovations have been mainly carried out by using our own resources, as we have a design department, a textile engineer on the staff, technicians specialized in product development, and people from other departments who are properly trained according to the needs of the company. We also had to resort to external services, such as laboratories, machinery suppliers, delivery and logistics services, etc."10

\footnotetext{
8 ATEVAL is the association of textile industries of the cluster, having offices in Ontinyent and Alcoi.

9 AITEX is an acronym of the Research Institute for the Textile Industry, an institute formed by the Government of the Valencian Region in the '90s whose objective involved the diffusion of technical expertise among its members.

10 Without doubt, profiting from the close cognitive proximity between these actors.
} 


\section{Beta company}

"The innovations were carried out by using our own resources, that is, internally and also with the help of external services such as laboratories, machinery suppliers, software, etc."

From both quotes, we can conclude that even though the companies are located in the same territory, they preferred to pursue their innovations by utilizing their own resources. The only external resources used by the firms included suppliers or laboratories, and they did not cooperate with other textile firms. In our opinion, after reviewing additional comments by these firms and by applying our own experience from other research studies of this territory, this finding could be attributed to a general attitude of industrial secrecy which arises due to the geographical proximity of competitors and the lack of collaboration between companies. In other words, this highlights one of the most obvious consequences of too much geographical proximity and too little social proximity (Molina-Morales \& Martinez-Fernández, 2009).

The utilization of internal resources offers advantages and disadvantages (Cainelli, De Marchi, \& Grandinetti, 2015). Some of the advantages include the possibility to integrate the results more easily, and the development process is quicker, as engineers and designers form part of the firm's staff (design is a fundamental part of product differentiation). However, all of this occurs without actively profiting from the aforementioned facilitating agents (e.g., universities and technological institutes), or from the creation of synergies between firms, in respect to R\&D activities, for example. For firms, this process requires significant economic effort, and the implementation of innovations is undertaken at a slower speed, which therefore affects their overall competitiveness. In addition, we should not forget that there is a lack of appropriation in terms of the efficiency of the intervention when several organizations carry out a project. Moreover, it should be acknowledged that product innovation also leads to necessary innovations in respect to the firm's processes, and in many cases, this involves innovations in the areas of marketing and organizational issues. Therefore, such forms of innovation necessarily arise from the changes that are introduced in product lines (Grabher et al., 2008).

In line with previous studies, such as the OECD's study (2005), it is interesting to note that these firms acknowledged the factors that foster and hinder innovation, as shown in Table 4. Among the factors which foster innovation, the firms mentioned a quick adaptation to customers' needs, a broader product portfolio, enhancing the level of quality, and knowledge exchange between other firms. Furthermore, both firms agreed that factors which hinder innovation include the high costs of innovation development and a lack of necessary knowledge and technologies. It must be mentioned 
that both of the firms which took part in this study were SMEs, and these factors might not be observed in the case of bigger firms.

Table 4. Summary of factors related to innovation cited by the interviewed firms

\begin{tabular}{|c|c|c|c|c|c|}
\hline Company & $\begin{array}{l}\text { Type of innovation } \\
\text { developed }\end{array}$ & $\begin{array}{l}\text { Resources } \\
\text { used in the } \\
\text { process }\end{array}$ & $\begin{array}{l}\text { Factors } \\
\text { mentioned } \\
\text { that fostered } \\
\text { innovation }\end{array}$ & $\begin{array}{l}\text { Factors } \\
\text { mentioned } \\
\text { that } \\
\text { hindered } \\
\text { innovation }\end{array}$ & $\begin{array}{l}\text { Proximity factors } \\
\text { mentioned by } \\
\text { companies }\end{array}$ \\
\hline Alpha & $\begin{array}{l}\text { Product } \\
\text { Process (Industry } \\
4.0 \text { ) } \\
\text { Organizational (Lean } \\
\text { Manufacturing) } \\
\text { Commercial (Online } \\
\text { sales, new channels, } \\
\text { low quantities } \\
\text { orders) } \\
\text { Servitization }\end{array}$ & $\begin{array}{l}\text { Own } \\
\text { resources } \\
\text { External } \\
\text { resources } \\
\text { (both from } \\
\text { inside and } \\
\text { from outside } \\
\text { the cluster) }\end{array}$ & $\begin{array}{l}\text { Increase market } \\
\text { share } \\
\text { Adapt more } \\
\text { quickly to } \\
\text { customers' } \\
\text { needs } \\
\text { Widen the } \\
\text { product } \\
\text { portfolio } \\
\text { Enhance the } \\
\text { quality level } \\
\text { Diminish } \\
\text { costs (Lean } \\
\text { manufacturing) } \\
\text { Increase } \\
\text { efficiency and } \\
\text { capacity } \\
\text { Knowledge } \\
\text { exchange } \\
\text { with other } \\
\text { organizations } \\
\text { To follow the } \\
\text { rules }\end{array}$ & $\begin{array}{l}\text { High } \\
\text { innovation } \\
\text { costs } \\
\text { Lack of } \\
\text { necessary } \\
\text { knowledge } \\
\text { Lack of } \\
\text { necessary } \\
\text { technology }\end{array}$ & $\begin{array}{l}\text { Social proximity: } \\
\text { firm comments } \\
\text { about low levels } \\
\text { of trust among } \\
\text { industry firms, } \\
\text { despite high } \\
\text { geographical } \\
\text { proximity } \\
\text { Institutional } \\
\text { proximity: firm } \\
\text { reports they } \\
\text { use cluster } \\
\text { institutions, but } \\
\text { complain about } \\
\text { their low level of } \\
\text { dedication; they } \\
\text { prefer playing } \\
\text { "petty politics" } \\
\text { rather than } \\
\text { keeping close to } \\
\text { the cluster firms } \\
\text { No comments } \\
\text { about } \\
\text { organizational } \\
\text { proximity } \\
\text { Cognitive and } \\
\text { geographical } \\
\text { proximities, } \\
\text { although not } \\
\text { mentioned, were } \\
\text { implicit in the } \\
\text { interviews }\end{array}$ \\
\hline
\end{tabular}




\begin{tabular}{|c|c|c|c|c|c|}
\hline Company & $\begin{array}{l}\text { Type of innovation } \\
\text { developed }\end{array}$ & $\begin{array}{l}\text { Resources } \\
\text { used in the } \\
\text { process }\end{array}$ & $\begin{array}{l}\text { Factors } \\
\text { mentioned } \\
\text { that fostered } \\
\text { innovation }\end{array}$ & $\begin{array}{l}\text { Factors } \\
\text { mentioned } \\
\text { that } \\
\text { hindered } \\
\text { innovation }\end{array}$ & $\begin{array}{l}\text { Proximity factors } \\
\text { mentioned by } \\
\text { companies }\end{array}$ \\
\hline Beta & $\begin{array}{l}\text { Product (New } \\
\text { technical textiles for } \\
\text { sports) } \\
\text { Process (Industry } \\
\text { 4.0, New raw } \\
\text { materials, new } \\
\text { technology) } \\
\text { Organizational } \\
\text { (Industry 4.0) } \\
\text { Commercial (New } \\
\text { brands, product } \\
\text { lines, and channels, } \\
\text { Internationalization, } \\
\text { Technical Assistance) } \\
\text { Servitization }\end{array}$ & $\begin{array}{l}\text { Own } \\
\text { resources } \\
\text { External } \\
\text { resources } \\
\text { (both from } \\
\text { inside and } \\
\text { from outside } \\
\text { the cluster } \\
\text { Attendance to } \\
\text { fairs } \\
\text { Technological } \\
\text { institutes }\end{array}$ & $\begin{array}{l}\text { Adapt more } \\
\text { quickly to } \\
\text { customers' } \\
\text { needs } \\
\text { Widen the } \\
\text { product } \\
\text { portfolio } \\
\text { Enhance the } \\
\text { quality level } \\
\text { Knowledge } \\
\text { exchange } \\
\text { with other } \\
\text { organizations } \\
\text { Enhance internal } \\
\text { communication } \\
\text { in the firm }\end{array}$ & $\begin{array}{l}\text { High } \\
\text { innovation } \\
\text { costs } \\
\text { Lack of } \\
\text { necessary } \\
\text { knowledge } \\
\text { Lack of } \\
\text { necessary } \\
\text { technology } \\
\text { Uncertainty: } \\
\text { Demand } \\
\text { can be low, } \\
\text { and hence, } \\
\text { innovation } \\
\text { costs cannot } \\
\text { be recovered }\end{array}$ & $\begin{array}{l}\text { Social proximity: } \\
\text { firm comments } \\
\text { about low levels } \\
\text { of trust with } \\
\text { industry firms, } \\
\text { despite high } \\
\text { geographical } \\
\text { proximity } \\
\text { Institutional } \\
\text { proximity: firm } \\
\text { reports they } \\
\text { use cluster } \\
\text { institutions but } \\
\text { complain about } \\
\text { their low level } \\
\text { of implication } \\
\text { and lack of } \\
\text { effectiveness. } \\
\text { No comments } \\
\text { about } \\
\text { organizational } \\
\text { proximity } \\
\text { Cognitive and } \\
\text { geographical } \\
\text { proximities, } \\
\text { although not } \\
\text { mentioned, were } \\
\text { implicit in the } \\
\text { interviews } \\
\text { Geographical } \\
\text { proximity: Firm } \\
\text { maintains extra- } \\
\text { cluster linkages }\end{array}$ \\
\hline
\end{tabular}

\section{Clustering effect on innovation: Opinions}

The firms' perceptions about the influence of their territorial location when innovating were described as follows:

\section{Alpha company}

"The cluster is valid to create synergies because we are in a territory where rivalry is very strong among companies that are dedicated to the textile industry. A few years ago, it was unthinkable that two competing companies located in the same industrial area would meet at an exhibition fair, an event, or even a meeting." 
"In principle, it is favorable for everyone, but lately, and from our point of view, these entities (Cluster Innovall, AITEX, ATEVAL ...) are more focused on representativeness, and they have not made an effort to be closer to companies ${ }^{11}$. When we have had to make an important change, we undertook the first step alone, it would be convenient that they were closer to the activity of the companies so that this happens as little as possible."

\section{Beta company}

"In general terms, the textile cluster of Ontinyent is favorable, but in my opinion, today, it does not have the media repercussion or the necessary impact for companies, that is, it does not mean an increase in market share or turnover. We created sportswear long before well-known brands like NIKE and ADIDAS, and due to a lack of media coverage, we were not able to sell them until these big companies put the same product on the market."

After analyzing the responses of both companies and reviewing the previous notes, we can conclude that both cases agree on the following aspects:

- belonging to a territorial cluster is important to carrying out innovation processes;

- innovation is carried out individually by internal mechanisms, with the help of external agents, but not other textile firms;

- there is a lack of coordination among the territory's institutions.

\section{DISCUSSION}

By considering the results of our research, and comparing them with the factors outlined in the literature review, we can state the following:

\section{Cognitive proximity}

The firms that participated in this study did not comment on cognitive proximity. Nevertheless, this type of proximity is understood to represent the shared knowledge base that enables communication between actors (Boschma, 2005), and it is regarded as a prerequisite for the cooperation of institutions within the cluster. At both the firm-level and the institutionallevel (e.g., ATEVAL, AITEX, or universities), this knowledge base formed part of the common ground between the actors.

11 We wish to note that the firm undoubtedly refers to a low level of institutional proximity. For example, while firms are demanding technical support to the institutions, the institutions only offer lobby influence in upper instances. 


\section{Social proximity}

We found that innovation development was carried out by the firms with the help of external suppliers, though not by cooperating with other textile firms. The competence level in the sector prevented the building of trust among the firms, which in turn negatively affected their level of cooperation. Beta company argued that an institution in the cluster, namely, ATEVAL, had the task of acting as a catalyzer for the development of trust among firms in the sector. Firms complained that this lack of social proximity was a deterrent to the formation of inter-firm linkages, which is in line with the conclusions of Molina-Morales et al.'s (2015) research involving another mature cluster that produced footwear products in Spain.

\section{Organizational proximity}

As a probable consequence of the low level of trust among firms, a low level of organizational proximity existed among them, which explained the lack of inter-firm cooperation when developing innovations. The manager of one of the firms in this study expected ATEVAL to act as a catalyzer to develop trust between the firms, by promoting trust-based networks of firms that could enhance organizational proximity. In this sense, it was implied that institutions, which are a key tenet of institutional proximity, could be used to promote organizational proximity, thus confirming Boschma's (2005) proposition regarding the substitutive effect, whereby some dimensions of proximity could be substituted for others.

\section{Institutional proximity}

Institutional proximity was not mentioned by the firms that were interviewed in this study, but it was "in the air." Sharing the same institutional framework ensured the stability of the industry (Bramwell et al., 2008), but firms were aware that some of the changes were prompted by actors who adopted this framework, namely, competing firms from Asian countries, which rendered useless the routine and conservative reaction to change (Herrigel, 1993). One firm complained about the lack of a "safety net" within this institutional framework, citing an instance related to their industrial property in an Asian country to which they exported.

\section{Geographical proximity}

Both firms are located within the cluster, whose geographical spread is reduced, though they keep extra-cluster linkages. These linkages help to 
reduce excessive geographical proximity, thus encouraging the firms to adopt a less inward-looking approach (Boschma, 2005). Both firms agreed that attending exhibition fairs helped them to keep up-to-date with technical developments within the sector, which decreased their need to engage with institutions in the cluster (AITEX, ATEVAL or Innovall)

\section{Development of innovation}

This study found that the two firms were concerned about innovation. However, in our opinion, their main objectives and challenges were to modernize their production processes, adopt more efficient production methods to reduce costs, acquire new machinery, develop more advanced production techniques, become more competitive, and aim to reduce their costs and prices. Both companies agreed on the following points: enhancing added value in their activities; applying the concept of servitization ${ }^{12}$; adding and integrating services to the supply of products, is a strategy that can be adopted by manufacturing companies to improve their competitive position. The representatives of these companies understand the importance of implementing technological innovations and organizational changes by means of the so-called Industry $4.0^{13}$ technology, which increases their efficiency and flexibility when faced with market needs.

\section{CONCLUSIONS}

By focusing on the implementation of innovation strategies, this study aimed to determine the mechanisms and level of coordination that exist in the most relevant textile cluster in Spain. As a result of the review and the fieldwork that were carried out, we can confirm that the innovations in the firms were developed in an isolated, discontinuous, marginal, and uncoordinated way, which suggests that clustering had a marginal effect.

However, by carrying out a detailed analysis of the information extracted from the interviews as well as our own observations, we found that both membership of a cluster and access to institutions (e.g., Innovall, AITEX, ATEVAL, universities, etc.) acted as an accelerator for these types of

12 Vandermerwe and Rada (1988) introduced this concept in a seminal article. Servitization is defined as a trend by which corporations are increasingly offering fuller market packages or "bundles" of customer-focused combinations of goods, services, support, self-service, and knowledge. The trend continues to pervade almost all industries. It is customer demand-driven, and corporations believe that it sharpens their competitive edges and helps them to establish new relations with customers.

13 Industry 4.0, referred to as the "Fourth Industrial Revolution", also known as "smart manufacturing", "industrial internet" or "integrated industry", is currently a much-discussed topic that supposedly has the potential to affect entire industries by transforming the way goods are designed, manufactured, delivered and paid. Curious readers can grasp a clear idea in Hofmann and Rüsch (2017). 
companies in regard to their innovation processes, as they are in a better position to generate synergies and information for their projects (Heinonen \& Ortega-Colomer, 2015).

Furthermore, we must outline another conclusion which highlights room for improvement among companies and institutions alike, and this point should be given adequate attention. The companies in the sample innovated without cooperating with other textile firms, which shows a lack of coordination between the companies and the cluster institutions (Sydow and Staber, 2002). We can only conclude that firms are not well-enough informed about how these institutions can contribute. The low level of trust that is present between longstanding competing firms, which is a by-product of too little social proximity, has not encouraged these firms to develop synergies among them. This situation should be redressed by the cluster institutions as well as by intelligent use of the tools available in the cluster, which would encourage cooperation and promote a win-win mindset that is aimed at establishing an entrepreneurial ecosystem (Jankowska, Götz, \& Główka, 2017).

We wish to emphasize the need to reinforce awareness among companies of the opportunity that is offered to them by virtue of their being located in a territorial cluster. This could encourage an increased level of specialization that would not be made possible in another location. In other words, by reinforcing awareness among companies of the advantages that arise from being located in a cluster, companies can appreciate that they possess a valuable strategic resource that other companies do not. They can gain a better appreciation of their position within an important network of scientific, financial, and support institutions that would render feasible a profitable knowledge transfer process. Thus, the seeds of the creation of an intelligent region would be sown, creating a continuous territorial development capable of outperforming many others (such as the GalicianPortuguese Fashion Cluster) ${ }^{14}$, because of the stable relationship between the scientific system and the productive system.

In short, the contributions of our study go beyond the academic (as evidenced by the innovation-territory relationship) to offer managerial and political insights. On the one hand, although the results show that being located in a cluster is a key factor for firms' survival in the textile industry, location, in itself, is not sufficient, as firms also need to cooperate and share ideas and experiences. On the other hand, in order to fully use the services provided by institutions (e.g., technological institutes, universities, or business associations) in their innovation processes, there should be

14 This cluster, EuroClusTex, was formed in 2009 and it is composed of 3,800 Portuguese firms and about 500 Spanish firms from several subsectors, all of which operate in the textile and fashion industry. Further information can found at: http://www.atp.pt/fotos/editor2/Ficheiros\%202010/Euroclustex_esp\%20(2).pdf 
greater interaction between institutions and companies ${ }^{15}$, and institutions should speak the language of companies and meet their needs. In other words, strong cluster initiatives are required (Freije, 2015; Lis, 2019) to reinforce the associative networking of the textile sector and thus avoid the "uncoordinated dance" in which it seems to be immersed.

Finally, we must recognize the limitations of our study in terms of the sample size employed. The sample consisted of only two companies. Although these companies belonged to different subsectors and had different governance schemes and product lines, this small sample can hardly be representative of a rich and varied industry such as the textile sector. This limitation highlights how further research can focus on institutions and workers that represent all of the actors that form the territory. One possible direction for future research would be to examine the effect of the different dimensions of proximity in the creation of linkages between entities, the relationships between this creation of linkages and the development of innovations, and to determine the extent to which diverse policies have contributed to innovation development. Another possible direction for future research would involve innovations that go far beyond the product and process innovations. While such innovations were developed and implemented in the cluster, organizational and marketing innovations remain less transparent. Therefore, studying the influence of the different dimensions of proximity in the development of these types of innovations would be a rich avenue of investigation.

\section{References}

Albors-Garrigós, J., Hervás-Oliver, J. L., \& Hidalgo, A. (2009). Analyzing high technology adoption and impact within public supported high tech programs: An empirical case. The Journal of High Technology Management Research, 20(2), 153-168. https://doi.org/10.1016/j.hitech.2009.09.006

ATEVAL. (2017). Estudio de impacto económico de la industria textil en las comarcas de la Vall d'Albaida, el Comtat y L'Alcoià, Ontinyent. Spain: Ateval. Audretsch, D. B., \& Feldman, M. (1996). Spillovers and the geography of innovation and production. American Economic Review, 86(3), 630-640.

Balland, P.A., Boschma, R., \& Frenken, K. (2015). Proximity and innovation: From statics to dynamics. Regional Studies, 49(6), 907-920. http:// dx.doi.org/10.1080/00343404.2014.883598

Baptista, R., \& Swann, P. (1998) Do firms in clusters innovate more? Research Policy, 27, 525-540. http://dx.doi.org/10.1016/S0048-7333(98)00065-1

Becattini, G. (2015). Beyond geo-sectoriality: The productive chorality of places. Investigaciones Regionales-Journal of Regional Research, 32, 31-41.

15 An easy way to reduce the institutional proximity. 
Blanc, H., \& Sierra, C. (1999). The internalization of R\&D by multinationals: A trade-off between external and internal proximity. Cambridge Journal of Economics, 23, 187-206.

Boschma, R. (2005). Proximity and innovation: A critical assessment. Regional Studies, 39(1), 61-74. http://dx.doi.org/10.1080/0034340052000320887

Bramwell, A., Nelles, J., \& Wolfe, D. A. (2008). Knowledge, innovation and institutions: Global and local dimensions of the ICT cluster in Waterloo, Canada. Regional Studies, 42(1), 101-116. http://dx.doi. org $/ 10.1080 / 00343400701543231$

Camisón, C. (2004). Shared, competitive, and comparative advantages: A competence-based view of industrial-district competitiveness. Environment and Planning A, 36(12), 2227-2256. http://dx.doi. org/10.1068/a3759

Cainelli, G., De Marchi, V., \& Grandinetti, R. (2015). Does the development of environmental innovation require different resources? Evidence from Spanish manufacturing firms. Journal of Cleaner Production, 94, 211220. http://dx.doi.org/10.1016/j.jclepro.2015.02.008

Canals, J. (2003). El sector textil-confección español: situación actual y perspectivas. Boletín ICE Económico: Información Comercial Española, (2768), 5-8.

Cerverón, V., \& Ybarra, J. A. (Eds.). (2016). La innovación empresarial en Ontinyent y su entorno. Alicante, Spain: Universidad de Alicante.

Claver-Cortés, E., Marco-Lajara, B., Seva-Larrosa, P., \& Ruiz-Fernández, L. (2019). Competitive advantage and industrial district: A review of the empirical evidence about the district effect. Competitiveness Review: An International Business Journal, 29(3), 211-235, http://dx.doi. org/10.1108/CR-08-2018-0048

Costa, M. T., \& Duch, N. (2005). La renovación del sector textil-confección en España. Instituto de Economía de Barcelona, (355/356), 263-272.

Delgado, M., Porter, M., \& Stern, S. (2010). Clusters and entrepreneurship. Journal of Economic Geography, 10, 495-518. http://dx.doi.org/10.1093/jeg/lbq010

Dyer, W. G., \& Wilkins, A. L. (1991). Better stories, not better constructs, to generate better theory: A rejoinder to Eisenhardt. Academy of Management Review, 16(3), 613-619. http://dx.doi.org/10.5465/ amr.1991.4279492

Edquist, C., \& Johnson, B. (1997). Institutions and organizations in systems of innovation. In C. Edquist (Ed.), System of Innovation. Technologies, Institutions and Organizations. London, UK: Pinter.

European Commission. (2019). Textile and clothing industries. Retrieved from https://ec.europa.eu/growth/sectors/fashion/textiles-clothing/eu_en

Freeman, C. (1987). Technical innovation, diffusion, and long cycles of economic development. In T. Vasko (Ed.), The Long-Wave Debate (pp. 295-309). Berlin, Germany: Springer. http://dx.doi.org/10.1007/978-3662-10351-7_21 
Freije, I. (2015). The role of cluster initiatives in strategic alliances: a view from the Basque Country region. Harvard Deusto Business Research, 4(1), 2-16. https://doi.org/10.3926/hdbr.62

Ghemawat, P. (2001). Distance still matters. Harvard Business Review, 79(8), 137-147.

Golf-Laville, E., \& Ortega-Colomer, F. J. (2012). Las fuentes de la innovación y el papel de las instituciones en el sistema de innovación de un distrito industrial. Arbor, 188(753), 75-96. http://dx.doi.org/10.3989/ arbor.2012.753n1006

Gordon, I., \& McCann, P. (2000). Industrial clusters: Complexes, agglomeration and/or social networks?. Urban Studies, 37, 513-532. http://dx.doi. org/10.1080/0042098002096

Grabher, G., Ibert, O., \& Flohr, S. (2008). The neglected king: The customer in the new knowledge ecology of innovation. Economic Geography, 84(3), 253-280. http://dx.doi.org/10.1111/j.1944-8287.2008.tb00365.x

Granovetter, M. (1985): Economic action and social structure. The problem of embeddedness. American Journal of Sociology, 91, 481-510. http:// dx.doi.org/10.1086/228311

Heinonen, T., \& Ortega-Colomer, F. J. (2015). Regenerative medicine as an emergent cluster in Tampere Region. Journal of Entrepreneurship, Management and Innovation, 11(4), 139-160. http://dx.doi. org/10.7341/20151146

Herrigel, G. B. (1993) Power and the redefinition of industrial districts. The case of Baden-Wurttemberg. In G. Grabher (Ed.), The Embedded Firm. On the Socioeconomics of Industrial Networks (pp. 227-251). London, UK: Routledge.

Hofmann, E., \& Rüsch, M. (2017). Industry 4.0 and the current status as well as future prospects on logistics. Computers in Industry, 89, 23-34. http:// dx.doi.org/10.1016/j.compind.2017.04.002

Jankowska, B., Götz, M., \& Główka, C. (2017). Intra-cluster cooperation enhancing SMEs' competitiveness-the role of cluster organisations in Poland. Investigaciones Regionales-Journal of Regional Research, 39, 195-214.

Lambert, S. C., \& Davidson, R. A. (2013). Applications of the business model in studies of enterprise success, innovation and classification: An analysis of empirical research from 1996 to 2010. European Management Journal, 31(6), 668-681. http://dx.doi.org/10.1016/j.emj.2012.07.007

Lazzeretti, L., \& Capone, F (2016). How proximity matters in innovation networks dynamics along the cluster evolution. A study of the high technology applied to cultural goods. Journal of Business Research, 69, 5855-5865. http://dx.doi.org/10.1016/j.jbusres.2016.04.068

Lis, A. M. (2019). The significance of proximity in cluster initiatives. Competitiveness Review: An International Business Journal, 29(3), 287310. http://dx.doi.org/10.1108/CR-08-2018-0050

Martin, R., \& Sunley, P. (2003). Deconstructing clusters: Chaotic concept or policy panacea?. Journal of Economic Geography, 3(1), 5-35. http:// dx.doi.org/10.1093/jeg/3.1.5 
Maskell, P. (2001). Towards a knowledge-based theory of the geographical cluster. Industrial and Corporate Change, 10(4), 921-943. http://dx.doi. org/10.1093/icc/10.4.921

Maskell, P., \& Malmberg, A.(1999). The competitiveness of firms and regions. 'Ubiquitification' and the importance of localized learning. European Urban and Regional Studies, 6, 9-25. http://dx.doi. org/10.1177/096977649900600102

Molina-Morales, X. (2001). European Industrial Districts: Influence of geographic concentration on performance of the firm. Journal of International Management, 7(4), 277-294. http://dx.doi.org/10.1016/ S1075-4253(01)00048-5

Molina-Morales, F.X., \& Martínez-Fernández, M.(2003).Theimpactofindustrial district affiliation on firm value creation. European Planning Studies, 11(2), 155-170. http://dx.doi.org/10.1080/0965431032000072855

Molina-Morales, F. X., \& Martínez-Fernández, M. T. (2009). Too much love in the neighborhood can hurt: How an excess of intensity and trust in relationships may produce negative effects on firms. Strategic Management Journal, 30(9), 1013-1023. http://dx.doi.org/10.1002/smj.766

Molina-Morales, F. X., Belso-Martínez, J. A., Más-Verdú, F., \& Martínez-Cháfer, L. (2015). Formation and dissolution of inter-firm linkages in lengthy and stable networks in clusters. Journal of Business Research, 68(7), 15571562. http://dx.doi.org/10.1016/j.jbusres.2015.01.051

Müller, J. M., Kiel, D., \& Voigt, K. I. (2018). What drives the implementation of Industry 4.0? The role of opportunities and challenges in the context of sustainability. Sustainability, 10(1), 247. http://dx.doi.org/10.3390/su10010247

Najda-Janoszka, M., \& Daba-Buzoianu, C. (2018). Editorial paper: Exploring management through qualitative research-introductory remarks. Journal of Entrepreneurship. Management and Innovation, 14(4), 5-16. http://dx.doi.org/10.7341/20181440

Nooteboom, B. (2000). Learning and Innovation in Organizations and Economies. Oxford, UK: Oxford University Press. http://dx.doi. org/10.1093/acprof:oso/9780199241002.001.0001

North, D. C. (1990) Institutions, Institutional Change and Economic Performance. Cambridge University Press, Cambridge. http://dx.doi. org/10.1017/CBO9780511808678

OECD. (2005). Manual de Oslo. Guía para la recogida e interpretación de datos sobre innovación, 3 a ed. Paris: OECD and EUROSTAT.

Porter, M. E. (1998). Clusters and the new economics of competition. Harvard Business Review, 76(6), 77-90.

Puig, F., González-Loureiro, M., \& Marques, H. (2014). Supervivencia, crecimiento e internacionalización en clústers industriales. Economía Industrial, 391, 133-140.

Puig, F., \& Marques, H. (2010). Territory, Specialization and Globalization: Recent Impacts on European Traditional Manufacturing. London, UK: Routledge. 
Rallet, A., \& Torre, A. (1999). Is geographical proximity necessary in the innovation networks in the era of the global economy?. GeoJournal, 49(4), 373-380.

Rodríguez-Victoria, O. E., Puig, F., \& Gonzalez-Loureiro, M. (2017). Clustering, innovation and hotel competitiveness: Evidence from the Colombia destination. InternationalJournalofContemporaryHospitalityManagement, 29(11), 2785-2806. http://dx.doi.org/10.1108/IJCHM-03-2016-0172

SABI. (2019). Sistema de Análisis de Balances Ibéricos, Bureau van Dijk. Retrieved from http://www.sabi.com

Saunders, M., Lewis, P., \& Thornhill, A. (2009). Research Methods for Business Students ( $5^{\text {th }}$ ed.). Harlow, UK: Pearson Education Limited.

Schmitz, H. (1992). On the clustering of small firms. IDS Bulletin, 23(3), 64-69. http://dx.doi.org/10.1111/j.1759-5436.1992.mp23003012.x

Schumpeter, J. A. (1982). The Theory of Economic Development: An Inquiry into Profits, Capital, Credit, Interest, and the Business Cycle (1912/1934). New Brunswick, NJ. Transaction Publishers. http://dx.doi. org/10.4324/9781315135564

Sivadas, E., \& Dwyer, F. R. (2000). An examination of organizational factors influencing new product success in internal and alliance-based processes. Journal of Marketing, 64(1), 31-49. http://dx.doi.org/10.1509/jmkg.64.1.31.17985

Solow, R. M. (1956). A contribution to the theory of economic growth. The Quarterly Journal of Economics, 70(1), 65-94. http://dx.doi. org $/ 10.2307 / 1884513$

Sydow, J., \& Staber, U. (2002). The institutional embeddedness of project networks: The case of content production in German television. Regional Studies, 36(3), 215-227. http://dx.doi.org/10.1080/00343400220122034

Taylor, S. J., Bogdan, R., \& DeVault, M. (2015). Introduction to Qualitative Research Methods: A Guidebook and Resource. Chichester, UK: John Wiley and Sons Ltd.

Tidd, J., \& Bessant, J. (2018). Managing Innovation Integrating Technological, Market and Organizational Change ( $6^{\text {th }}$ ed.). Hoboken, N.J.: John Wiley and Sons Ltd.

Tognazzo, A., \& Mazzurana, P. A. M. (2017). Friends doing business: An explorative longitudinal case study of creativity and innovation in an Italian technology-based start-up. Journal of Entrepreneurship, Management and Innovation, 13(2), 77-104. http://dx.doi.org/10.7341/20171324

Torre, A., \& Rallet, A. (2005). Proximity and localization. Regional Studies, 39(1), 47-59. http://dx.doi.org/10.1080/0034340052000320842

Vandermerwe, S., \& Rada, J. (1988). Servitization of business: Adding value by adding services. European Management Journal, 6(4), 314-324. http:// dx.doi.org/10.1016/0263-2373(88)90033-3

Von Krogh, G., Spaeth, S., \& Lakhani, K.R. (2003). Community, joining, and specialization in open source software innovation: A case study. Research Policy, 32(7), 1217-1241. http://dx.doi.org/10.1016/S00487333(03)00050-7 
Yin, R.K. (2018). Case Study Research and Applications: Design and Methods ( $6^{\text {th }}$ ed.). Thousand Oaks, CA: Sage.

Uzzi, B. (1997). Social structure and competition in interfirm networks: The paradox of embeddedness. Administrative Science Quarterly, 42(1), 35-67. http://dx.doi.org/10.2307/2393808

\begin{abstract}
Abstrakt
Biorqc pod uwage proces rozwoju innowacji, celem niniejszego artykułu było zbadanie wpływu różnych wymiarów bliskości i poziomu koordynacji istniejqcej w klastrze włókienniczym. $W$ badaniu zastosowano metodę jakościowq, opartq na pogłębionych wywiadach przeprowadzonych z dwoma wiodqcymi firmami w klastrze tekstyInym w Walencji, w Hiszpanii, który jest przedmiotem intensywnej konkurencji producentów z Azji. Firmy zostały wybrane według kryteriów rozwoju innowacji i możliwości. Jest to badanie pilotażowe, które poprzedza bardziej zaawansowane. Wyniki sugerujq, że innowacje firm sq rozwijane w sposób izolowany, nieciqgty, marginalny i nieskoordynowany, a grupowanie ma marginalny wpływ. Ponadto, pomimo dużej bliskości geograficznej i poznawczej, niewielkq bliskość społecznq utrzymuje się niski poziom zaufania między firmami. Te ustalenia mogq mieć znaczqca wartość praktycznq dla praktyków i instytucji. Firmy mogq lepiej zrozumieć znaczenie lokalizacji w klastrze, ponieważ jest to kluczowy czynnik ich przetrwania w warunkach intensywnej konkurencji. Jednak bliskość geograficzna nie jest wystarczajqca, a firmy muszq ze sobq współpracować i dzielić się swoimi pomysłami i doświadczeniami. Ponadto instytucje powinny w większym stopniu współdziałać z firmami, mówić ich językiem, zaspokajać ich potrzeby i opracowywać silne inicjatywy klastrowe. Badanie to zapewnia pełniejsze zrozumienie tego, $w$ jaki sposób instytucje i firmy współdziałaja $w$ ramach klastra $w$ procesie rozwoju innowacji, oraz opracowuje różne wymiary bliskości między firmami. Słowa kluczowe: klaster, innowacje, bliskość, Hiszpania, terytorium, odzież tekstylna
\end{abstract}

\title{
Biographical notes
}

Emilio Camarena-Gil is a Lecturer at the Faculty of Economics of the University of Valencia. He owns Bachelors' degrees in Mechanical Engineering and Business Administration, and a Master's degree in Business Strategy. With extensive experience in private companies in commercial and managerial positions, he teaches Business Management in Bachelor's, Postgraduate and Executive Education programs.

Carlos Garrigues-Ortola is a researcher in the research group GESTOR (Business Geo-strategy) at the University of Valencia. He owns a Bachelor's degree in Business Strategy. He has considerable experience in textile firms and he has participated in different conferences and projects related to innovation and industrial clusters. 
Francisco Puig is a Senior Lecturer in the Department of Management of the University of Valencia (Spain). He completed his Ph.D. in Economics and Business (with honors). He has been an international visiting lecturer in many universities, such as Kings College London and Manchester Business School. He specializes in international strategy and clustering and has published articles in leading journals as well as co-authored books and chapters in collective volumes.

\section{Conflicts of interest}

The author sdeclare no conflict of interest.

\section{Citation (APA Style)}

Camarena-Gil, E., Garrigues, C., \& Puig, F. (2020). Innovating in the textile industry: An uncoordinated dance between firms and their territory? Journal of Entrepreneurship, Management and Innovation, 16(3), 47-76. https://doi. org $/ 10.7341 / 20201632$ 